\title{
A New Look At Management Accounting
}

Mohammad Talha, King Fahd University of Petroleum \& Minerals, Saudi Arabia

John B. Raja, Multimedia University, Melaka, Malaysia

A. Seetharaman, S P Jain Center of Management, Singapore

\begin{abstract}
This paper presents a comparison of the traditional management accounting with the new approach of management accounting with the use of latest information technology and manufacturing technologies. The information and data of the research were gathered from various sources of secondary data. Many online articles and journals were available through these search engines such as Google, Infoseek, Lycos, Excites and Altavista. These articles were downloaded from Internet Websites including IFAC library, CPA online newsletters, Institute of Management Accountants, CIMA (Chartered Institute of Management Accountants), Technical Bulletin and Institute of Commercial and Financial Accountants. The modern techniques used in Management Accounting are discussed. TQM (Total Quality Management), ABC (Activity Based Costing) and BSC (Balanced score card) are some of the tools that are introduced in management accounting to keep up with the latest technology. This research highlights the emergence of new, more proactive management accounting that increasingly becomes part of the management team with the business process. The future roles and expectations of these accountants in the competitive global economy are discussed.
\end{abstract}

Keywords: Management accounting, Standard Costing Activity based costing, Balanced Scorecard, Information Technology

\section{INTRODUCTION}

$\mathscr{T}$ anagement Accounting is a process of providing financial and non-financial information for managers. Managers need to include information for planning and controlling either short or long-term decisions. Management Accounting covers all levels of management from senior managers to shop floor supervisors. It also provides information for costing of goods, services and organizational units. Management accounting systems are designed to produce regularly required information especially budgeting, performance report and product costs. The concern on management accounting has become more popular since 1987 when Johnson and Kaplan discussed that the Management Accounting was not keeping step with the latest technology. Changes in business environment, reduction in import tariffs, deregulation of the finance sector, new employment practices, and increased importance of service sector and implementations of new practices are the major factors that influence Management Accounting. The current changes in manufacturing technology and information technology has made Management accounting more advanced. The accounting system encourages and motivates managers and other employees for the use of information technology. It focuses also on customers' requirement by providing customer satisfaction to gain more profit and more customers. The evolution and adoption of management accounting to meet the changing needs in today's world is much appreciated by many organizations. Management accounting practices are likely to develop broad spectrum of cross-functional disciplines. Specific directions include performance management, intellectual capital management, environmental management, financial management, asset management, information management and strategic management.

\section{RESEARCH PROBLEM}

A new look at management accounting was needed because management accounting was not keeping step with the latest manufacturing technologies and management philosophies. This concern included matters such as product costing, capital investment appraisal and non-financial performance measures. In modern times, most of the management accounting, process has been automated especially through the use of latest Information Technologies. 
This leads us to question whether management accounting has been too slow to change despite the rapidly changing technology. Essentially, the research problems are summarized as below: -Lack of management accountant expertise with IT knowledge has made the development of management accounting to be slow. The unawareness of relative benefits of traditional and emergent management accounting practices are affected by size of organization, industry (manufacturing or non-manufacturing) or organization strategy itself. How have the technological changes caused major effects on the nature of management accounting? How traditional based management accounting approach may be solved by a future based approach of management accounting?

\section{OBJECTIVES OF THE RESEARCH}

The objectives of this study are as follows:

- $\quad$ To identify the future direction of the New Management Accounting and its evolution

- $\quad$ To analyze the concern of management accounting in keeping step with the latest information technology and manufacturing technologies

- $\quad$ To anticipate trends in the environment and features of business firms on how Management Accounting is changing in the future

\section{SCOPE OF THE STUDY}

The management accounting emerged as a product of the Industrial Revolution. This study focuses on the new approach of management accounting in keeping up with the latest Information technologies and Manufacturing technologies. The research also highlights the emergence of new and more 'proactive' management accounting that is changing despite the emergence of rapidly growing information age.

\section{SURVEY OF LITERATURE}

Hofstede (1983) conducted a research and it has resulted in the recognition of five factors of cultural diversity. This model is now examined in the context of its relevance for management accounting and control. He also believes that global organizations must consider the impact of cultural differences on its management accounting and control systems. The author's power distance theory contributes to more successful management accounting and control system. Its most significant impact is seen in the case of budget formulation. Budgets that are commonly used for the qualification of organizational goals and targets are often ineffectively managed. By considering power distance this problem could greatly reduce through the tailoring of the budgetary system. This is achieved by firstly ascertaining the level of power distance in the workforce. His final step will be to formulate a demanding budget that gets the best out of employees who feel that they are in a comfortable working environment. This whole dynamic allies itself with modern management accounting concepts such as the Balanced Scorecard so that management's scope is not restricted to financial indicators alone. However the article did not mention about the companies, which have successfully implemented this method. It also did not mention on how different cultures do business and will impact management accounting.

Alfred Rapport (1986) in his book suggested seven value drivers; sales growth, operating profit margin, tax rate, working capital investment, fixed asset investment and weighted average cost of capital and the competitive advantage period. Value based metrics take these value drivers and summarize them into a single measure that is proliferating. Balanced Scorecard seeks to broaden measurement to non-financial areas and to consider a range of stakeholders, value based metrics seek to focus on financial performance and shareholders. The awareness of the new performance measures was low, with $26 \%$ being unaware of EVA and similarly being unaware of the balanced scorecard. Even more concerning was the lack of awareness of an established measure such as Residual Income by qualified management accountants. However traditional accounting measures are still dominant in practice. Current low level of adoption is due to lack of awareness fad and genuine technical problems in implementing these new measures, particularly at divisional level.

Johnson and Kaplan (1987) expressed that the failure of management accounting practices to adapt quickly to the needs of the new enterprise could be attributed to two primary reasons. First, there was a new and powerful 
accounting profession after World War 1 that stipulated rigid financial reporting rules. These rules carried a high compliance cost that prohibited the development of management and control systems for more effective decisionmaking. Second, accounting educators increasingly encouraged the use of financial accounting information for managerial decision-making and indoctrinate (instruct) the mindset of future business managers. They also commented that there has been a rapid growth of new management practices for improved decision-making. These include activity based costing and management (Cooper and Kaplan, 1991; Cooper 1992); the balanced scorecard, (Kaplan and Norton, 1992); quality (Deming, 1986; Oakland, 1989; Hill 1991a; 1991b; Petty.1997) and benchmarking (Balm, 1992; Bogan and English, 1994). However an unsettled issue in this article is whether these emergent practices have complemented or substituted traditional management accounting practices such as budgeting, absorption costing cost volume profit analysis, variable costing and target costing. The article also was unable to determine in detail on the size, industry and strategy that could influence the selection between traditional and emergent management accounting practices.

John Corrigan (1987) believes that Management Accounting has emerged as a key component of the profession, and is gathering further strength at both national and international levels. Management accounting evolved to such an extent that is now challenging the lead, as the accounting profession as a holistic approach for the new millennium. The dynamics of today's business landscape have provided a fertile environment for the renewed interest and focus on the role of management accounting in business. However the author did not mention on how management accounting practice be developed, usefulness of management accounting practice and finally how management accounting work technologies be tested?

Drucker P.F (1990) mentions that traditional cost accounting hardly provide the information to justify "a products improvement, let alone a product or process innovation". Rigid rules cannot be laid down for the management accounting system, which fulfils the requirements of the TQM environment. The need is for the management accountant to remain closely in touch with the changes in the working environment and to play a constructive role in the direction giving of these changes. Management accounting system should focus on these factors. Greater awareness of customer needs by means of a series of performance measures (Kaplan \& Norton 1992).Provide more opportunity for identifying costs and measures of processes, in contract with products and the movement to cross functional structures in cost gathering and Control (Greenwood \& Reeve 1992) Aids by which to determine accurate quality costs which includes the costs and benefits which related with prevention, appraisal and failure (Dale 1992). Increasing use of non-financial performance measure which are combination of strategic and operating elements of enterprise.

Gerald Ross (1990) believes the transformations in Management Accounting Profession, provides a snapshot of the current state of the management accounting profession. The key components to their quality improvement programs of management accounting focused on serving their "internal customers". Management accountants work closely with their "customer" to provide the right information and helps to use the information to make better decisions. Ross predicted the changes underway for management accounting. The author feels that to survive and flourish in the new technological world, management accounting would need to begin using more sophisticated tools and move from the operational level into the strategic level.

Yasuhiro and John (1993) examined Kaizen costing, a critical means of ensuring continuous improvement activities used by Japanese auto makers, supports the cost reduction process in the manufacturing phase. This approach employed together with target costing and kaizen costing helps Japanese manufacturers achieve their goal of cost reduction in the entire product design development production cycle. The authors commented that Japan's kaizen costing calls for the establishment of a cost reduction target amount, and its accomplishment through kaizen activities such as continuous improvement in operations. They also define kaizen costing activities as those that sustain the current level of the existing production costs, and further reduce it to the expected level based on the company plan. These cost improvement activities are very specific with respect to each department and each accounting period. The periodic cost improvement process is preceded by the annual budgeting process, or shortterm profit planning process. The authors stated that Kaizen costing is implemented outside the standard cost accounting system and is not limited by the financial accounting focus of the standard costing system by Japanese automakers. The strength of Kaizen costing comes from its close link with the profit planning process of the whole company. This consistent connection with the overall planning and budgeting process ensures that the company can 
monitor its progress toward the long-term goals without being confined to the tasks of meeting cost standards and investigating variances in conventional cost control systems. The limitation of this article is that the authors did not provide detailed comparison between kaizen and target costing.

Ragnar Gotestam (1994) mentioned that government commissioned the National Board of Health and Welfare to observe the development of new management accounting systems in social services. He described that the introduction of the new management accounting has coincided with changes and efficiency measures in local government activities and the introduction of new systems of user charges. The new local government act and a new system of state grants for municipalities have reduced the element of management by instruction. Nearly all municipalities made themselves available for their increased liberty to decide the structure of municipal committees and administrative authorities for themselves. The greater part of social service activities are still being conducted under public auspices, but contract based operation increased between 1991 and 1993. Most municipalities have introduced profit centers with cost and profit accountability in social service. However a risk of the new steering procedures resulting in short-term cost efficiency being given priority over the long term variety and in what is good for the individual unit carrying more weight that what is good for the organization as a whole. The article also did not mention on how modified steering systems have affected the quality of social service activities.

Lee (1994) summarized that product life cycles getting shorter and shorter and traditional standard costing systems are no longer effective. The author believes that a new cost management concept, target costing, has allowed companies to win considerable amount of market shares. Based on the price down, cost down strategy, target costing places emphasis on the firm's relative position in the market and product leadership. Because it is closely linked with the firm's long term profit and product planning process, target costing allows the company to focus on profit and product in an integrated strategy that does not discriminate against high quality, high price, high margin products that require high costs. Profit is determined based on the desired return on sales rather than return on investment. The allowable cost of a product is compared to its estimated cost, and then a target cost is established. Engineering planners then decompose target cost into each cost element and use value engineering to achieve the target cost. The author describes that the target sales price is established based on market research; the desired profit is subtracted to yield the allowable cost. This is a target, which is very hard to attain, usually impossible in the short run. The desired profit is determined based on the company's desired return on sales (ROS), rather than ROI. The limitation to this article is that the author did not elaborate or provide enough explanation on the ineffectiveness of the traditional standard costing system compared to target costing.

Mouritsen (1995) describes that the role of management accounting in international firms is related to their strategies of co-ordination and integration. In the global firm, management accounting supports a dispersed configuration of the value-chain located across the world. The dispersed location of activities calls for extensive coordination and central management intervention in the affairs of its subsidiaries. Through attention to global product line profitability, central management can use management accounting to establish an integrated organization. Production, sales, R\&D, etc. are positioned globally according to specific location advantages and they are integrated through planning and budgeting activities. Management accounting in global firm is fine-tuned information mechanism. It relies not only on composite financial measures but also on non-financial measures that help integrate different subsidiaries in the furtherance of global rather than local objectives. Thus the main task of management accounting is to support the management to co-ordinate all the global business activities and to integrate them through planning and budgeting activities. However the author did not give example of the implementation of management accounting in the international firm and also what are the strategies used in support of management accounting on the global financial market.

Jones, Munday and Brinn (1998) debated on the role of the UK management accountant as a barrier to the adoption of Japanese management accounting techniques, highlighting professional and cultural differences, which could make UK management accountants reluctant to convert to Japanisation. The authors argued that such reluctance in a key functional area might, in turn, hinder the importation of closely related Japanese production techniques and adversely impacting the competitiveness of UK manufacturing. The debate involves on the extent of the Japanisation of UK industry by speculating whether Japanese management accounting, particularly preproduction costing, might be adopted in the UK. The authors argued that the different background and status of the UK management accountant pose an impressive barrier to Japanisation. Hence the authors believe that successful 
adoption will be prevented by social, not technical considerations. This conclusion has a wider pertinence because the critiques of Japanese cost and management techniques show their pivotal and supportive role in the successful development of Japanese production systems. The authors highlighted that if UK manufacturing organizations are unable to adopt Japanese management accounting methods then the importation of interconnected Japanese production techniques such as JIT and kaizen will be inhibited, adversely affecting UK manufacturing competitiveness. The authors agrees to the suggestion that the successful Japanisation of production will occur only in conjunction with extensive organizational redesign, particularly in the management accounting functions which have some self interest in the vertical transmission of historical financial data rather than the horizontal dissemination of information supportive of cost management and kaizen. However the authors hypothesized that UK management accountant's act as a barrier to the mediated Japanisation of management accounting but failed to provide an empirically based research to test these arguments.

Louis J Sarasohn (1999) has mentioned in his article that management accounting is the final product of some system or process. Management accounting should be done in a proactive way. This situation limits management accounting prospect for adding value, and it also highlights the need for their earlier involvement in the process. The management accounting can be involved in the feasibility studies, requirement definitions and frontend designs to ensure that the final products really meet the needs of the company and its end users. The management accounting role in organizational survival is grounded in the anticipation of changes in the operating environment and the ability through strategic planning, to take advantage of changes. Management accountings need to support strategic planning and process improvement to ensure organizational success. In this regard, management accounting must be involved early in the process through strategic planning, process improvement or some other organizational need.

Erkki K Laitinen Rolf Leppanen. (1999): analyzed the strategic steering and management accounting systems as determinants of global success through Case study method. The study concentrates on the case of Nokia Group on the corporate level. The case describes the strategic elements of corporate management; since it is believed that understanding these elements will explicate to some extent the overall economic success of the company playing in the global arena. In general he believes that global success is a determinant of large number of factors, such as environment, management, products, strategy system and information systems. It's worthwhile to notice that the new management accounting designs and general ideas tend to converge globally on a global management accounting practice model.

John Flohr Nielsen's (1999) recent research describes the implementation of new accounting system. He believes that the Management accounting may be perceived both as a limitation and as a support for new customeroriented initiatives. He says that generally the success of new systems should preferably be evaluated in terms of their use in decision-making, though researchers often rely on measures based on management evaluation of success. In companies attempting to strengthen their customer orientation, the success of new management accounting system should be measured according to their usefulness in decision making in customer related decisions and for the organizations. The research also provides evidence of several barriers, which have to be overcome before more customers oriented management system, can be successfully implemented in financial companies. The survey results do not however, indicate what kind of profitability calculations the financial firms are using for analyses.

Ellram (1999) examines supply management's role in the target costing process. The author commented that supply management tends to have very specific roles and responsibilities at each step of the target costing process. The author highlighted that in the early steps of target costing; supply management identifies capable suppliers, facilitates early supplier involvement, and qualifies suppliers while verifying their capabilities and performance history. Supply management also plays a primary role in negotiation and development of long term agreements with suppliers. The author also gave an overview of supply management's active role in monitoring the ongoing cost and performance of suppliers once a product or service is introduced. Most of the organizations researched have a means of tracking actual performance versus target cost. Therefore, target costing continues in a fashion throughout the life of the product. The author also stressed that in order to understand the key issues and concerns of critical target costing process supply management's involvement has a higher responsibility throughout the new product development. The author also commented that all manufacturing companies in her research use 
target costing for unique raw materials and components. The author pointed out that most of the organizations analyzed, use target costing for high value or critical purchases and further elaborated that target costing is not only used for standard raw materials, but also for services, packaging materials, outsourcing, tooling and capital. Finally the author concluded that target costing is a very resource intensive process and it requires a team effort to be successful. The author did not elaborate in detail on supply management's responsibility during new product development and no examples was discussed on organizations that use target costing for high value or critical purchases.

Brewer C Peter (2000) in his article describes that traditional management accounting practices such as standard costing and contribution margin analysis continue to be prevalent. The traditional topics, when coupled with all the recent advancement, create sizeable body knowledge that present a challenge to management accounting educators, who bear the responsibility of organizing this subject matter into a coherent whole. In an effort to aid professors wrestling with this challenge, a new framework is presented for organizing an entire management accounting curriculum. Traditional management accounting practices such as standard costing and contribution margin analysis continue to be prevalent. The article discusses the organization and limitations of the accounting curriculum that existed at Miami prior to change advocated. He mentions that the ethical and environmental contexts theme recognizes the importance of bringing ethical values and an appreciation for the environment. The activity orientation however recognizes that strategies are created and ultimately operational by understanding and managing the activities across the supply chain that deliver value to customer. However the article only presented one method (being used at Miami) for applying this curriculum framework to the classroom. Hopefully, additional insights will emerge in the future as to how other institutions are applying this framework.

Burns John E, Scapens, R. (2000) claimed that management accounting is changing despite the rapidly changing technological and organizational environment in recent years. He highlighted on the emergence of new, more 'proactive' management accountants who increasingly becoming part of management team within a business process. He believes individuals must be prepared to accept and have organizational backing to change traditional 'ways of doing' accounting and prepared to accept exciting challenges ahead. He explained that there have been tremendous advances in information technology. Apart from the speed and capacity of modern system, there also have been the database technologies that provide the ability to store vast amounts of information in easily accessible way. These technologies permit various users to access the information stored on the database at the same time and may use it in different ways. With the current information system, accountants are able to produce both financial and management accounting reports in more presentable manner. However, this survey was unable to identify changes in the way that traditional accounting techniques are now in practice. No attempt was also made to access the impact of external factors.

Randall J Cloud (2000) contemplates that the management accounting must take lead in furnishing companies with customer oriented information. Finance and accounting professionals need to reserve the side effects of standard costing, highlight the financial impact of current practices, and focus their organizations on the results of managing the supply chain. Once distribution and production processes have been developed around market demands, it's time to look at material management. To develop and manage systems that support fast, on time distribution networks and quick, flexible production processes, companies must transcend traditional organizational boundaries and include suppliers in the planing and administration of operations. The article however, did not clearly define the areas for improvement in Management Accounting and the article focuses on supply chain management.

Tom Kennedy and Richard Bull (2000) have discussed in their article that the traditional management accounting system was aimed to offer neutral, objective and calculable financial information. These systems were expected to bring to light the facts of costing, to enable the pursuit of efficiency and help better regulate management-labor relations. They mentioned that it was this perceived "lost relevance" that has triggered the development of Activity Base Costing (ABC) in the mid 1980's. It purports to undo the problems of conventional management accounting by providing an organization with strategic, operational, financial and non-financial information. It recognizes that business is a series of linked activities and processes that are undertaken to server the customer and to deliver product attributes. $\mathrm{ABC}$ therefore, is the generic term to describe an alternative paradigm to traditional volume based cost model. The study claims that it is an accounting approach aimed primarily at 
understanding causality and giving decision makers the potential to manage costs at root rather than to focus on product cost only. The study is confined to the manufacturing industry that has to contend with large overhead costs. They also did not provide the type of information required in today's highly competitive and global environment.

Gary Siegel (2001) has explained that the management accounting has made a quantum leap. Over the past 10 years, management accountants have been transformed from "bean counters" and "corporate cops" on the periphery of business decision making to "business partners" and valued team members at a very clear center of strategic activity. Escalating change in the profession in the past five years continues to enhance the role of management accountants in a growing number of American companies and to increase the value of their contribution to business.

Juun-Min Lee, Richard C W Chen, Injazz Chen, Chen H Chung (2002) examined Strategic Decision Support Systems (SDSS) which is based on a market driven target costing strategy. They have highlighted that in order to effectively accomplish strategic goals; such a strategic decision support systems should be incorporated into a firm's enterprise resource planning system. An enterprise resource planning system intends to integrate and automate traditional back office functions such as finance, human resources, operations, and many more. They have addressed four types of strategic decision support systems requirements associated with target costing. The first is the general strategic decision support activities such as environmental scanning, technological forecasting, scenario planning and market analysis. These tasks are essential to a firm's overall strategic planning process. The second group of requirements belongs to the company's Activity Based Management Systems (ABMS). One of the key tasks of an ABMS is the analysis of activities and costs and their relationships. Therefore, the third group of decision support requirements is referred to as the firm's Business Process Reengineering (BPR) activities. Here, the evaluation of the impacts of information technology (IT) often becomes a dominant consideration. Finally, the analysis of product or process costs is one of the most important tasks in a firm's product design activities. The authors also highlighted the limitations of the strategic decision support systems, as existing enterprise systems have not lived up to the above expectations and are criticized for being a patchwork of enterprise programs. The authors also pointed out that the decision support capabilities, particularly those for strategic planning activities, of the existing enterprise are generally lacking. The authors failed to provide examples on organizations that adapts to the strategic decision support systems as their target costing.

Erkki K. Laitinen (2006). This research is done on primary data collected from 145 firms in Finland about the management practices followed by firms. The study has resulted in identifying four factors namely organizational factors, financial factors, motivational factors and management tool factors. Organizational factors discusses on variables on status, organization, strategy, products, perceived uncertainty, and competition. Financial factors are traditional financial ratios. Motivational factors may decelerate or accelerate Management accounting change. Management tools factors describe tools used by the management. The author has used structural equation modeling for analyses. The study is restricted to Finland firms only.

Markus Granlund (2009). In this article the authors discussed the need and importance of theory in management accounting. These theories should provide justification for the use and how it is going to benefit the stakeholders. Majority of the theories are taken from interrelated areas but no theory relating to management accounting. These theories dose not help the management accounting professional and practitioners. Management accounting theories should take into consideration the changing economic environment both domestic and international scenarios. The authors finally conclude with how better theories can be developed in the liberalized competitive situations for achieving optimum use of resources.

\section{RESEARCH METHODOLOGY}

The information and data of the research were gathered from various sources of secondary data. With the existence of the latest information technology, Internet search engine has provided information for supporting this research. Many online articles and journals were available through these search engines such as Google, Infoseek, Lycos, Excites and Altavista. These articles were downloaded from Internet Websites including IFAC library, CPA online newsletters, Institute of Management Accountants, CIMA (Chartered Institute of Management Accountants), 
Technical Bulletin and Institute of Commercial and Financial Accountants. References were also made available from various accounting and financial university online libraries. The research framework is developed in Figure 1 as below:

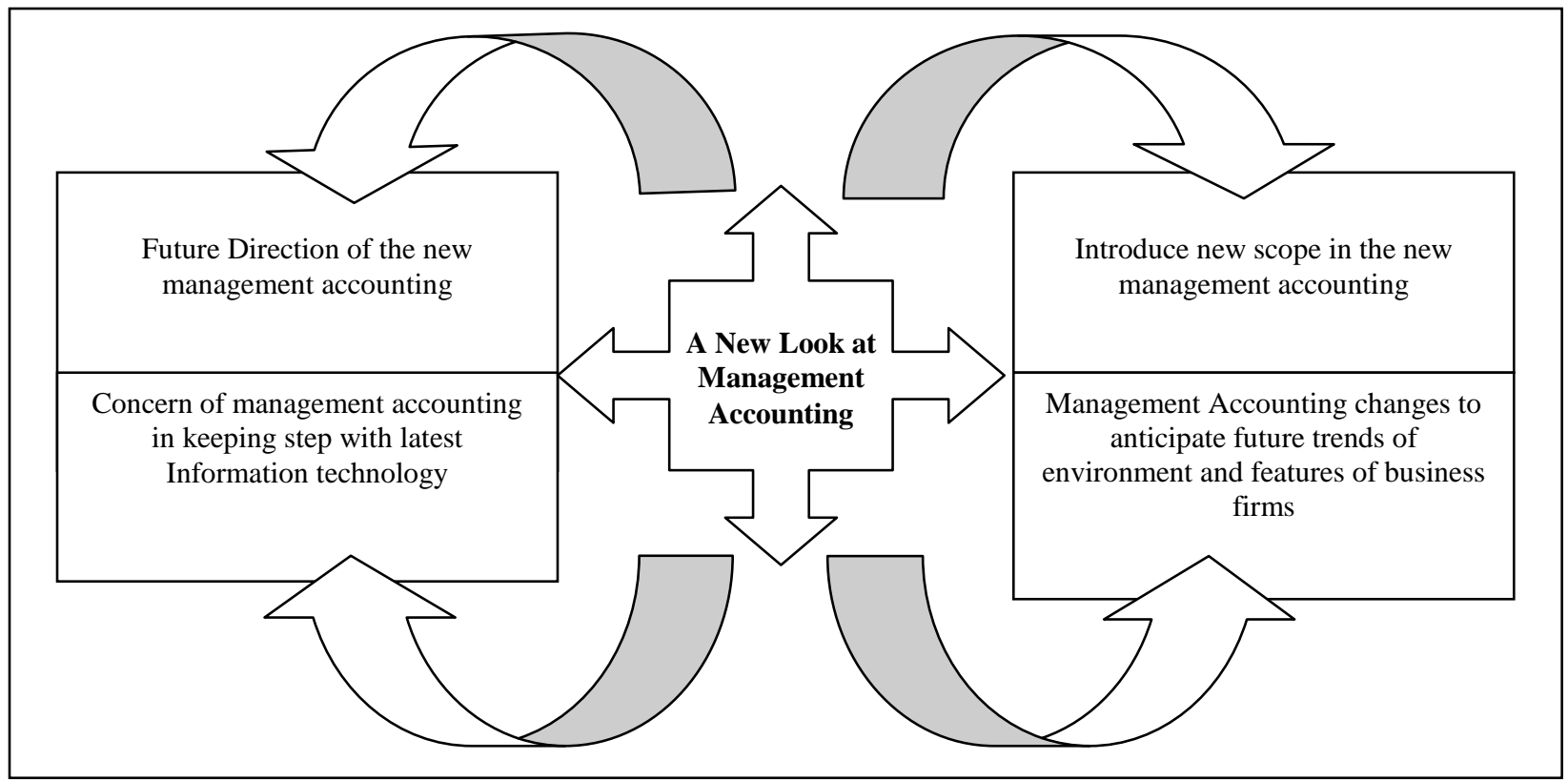

Budgeting, variance analysis and return on investment techniques will continue to be adopted by organizations, but new techniques are likely to assume greater relevance. Management accounting should focus on performance management, asset management, business control management, environmental management, financial management, intellectual capital management, Information management, quality management and strategic management. The relative importance of each of these directions to business will be driven by the organizational context. The contextual features of the business, is particularly the size and nature of the industry. Individual business needs would be critical in determining the level of emphasis placed on each of these directions.

\begin{tabular}{|l|l|}
\hline Strategic indicators & Tools for analyses \\
\hline Performance Management & $\bullet \quad$ Benchmarking \\
& $\bullet \quad$ Key financial and non-financial performance indicators \\
& $\bullet \quad$ Shareholder wealth maximization and customer value creation \\
& $\bullet \quad$ Value chain analysis \\
\hline Corporate Finance & $\bullet \quad$ Target costing \\
\hline Information Management & $\bullet \quad$ Measuring and managing business and financial risk \\
\hline Quality Management & $\bullet \quad$ Electronic commerce and electronic data interchange \\
& $\bullet \quad$ Outsourcing information systems \\
\hline & $\bullet \quad$ just-in-time production systems \\
\hline & $\bullet \quad$ Costs of quality \\
\hline
\end{tabular}


Management Accounting Evolution

1950: Focus was on cost determination and financial control through the use of budgeting and cost accounting technologies.

1965: Focus shifted to the provision of information for management planning and control, through the use of such technologies as decision analysis and responsibility accounting.

1985: Emphasis on the reduction of waste in resource used in business processes, through the use of process analysis and cost management technologies.

1995: Attention had shifted to the generation or creation of value through the effective use of resources, through the use of information technologies, which examine the drivers of customer value, shareholder value and organizational innovation.

2000: Controlling inventory and distribution costs by using supply chain management.

The evolution represents adaptation to a new set of condition facing organizations, by absorbing, reshaping and addition to the focus and technologies used previously. Each evolution is a combination with old reshaped to fit with the new in addressing a new set of conditions in the management environment. The critical difference in the shift between 1965, 1985 and 1995 is the change in focus away from information provision and towards resource management, in the forms of waste reduction (1985) and value generation or creation (1995). The focus now however is on reducing the loss or waste of this resource (in both financial and real terms) and on conserving its use in value generation.

\section{NEW SCOPE IN THE MANAGEMENT ACCOUNTING}

Management accounting will have to make significant changes to the way they operate within organizations in the next millennium. To keep up with the changes, new accounting models were created. One of it is the Activity Based Costing ( $\mathrm{ABC}$ ). $\mathrm{ABC}$ is one of the methods that have been hailed as the answer to the changing needs, and this has given to other applications such as activity-based management and shareholder-value analysis. Traditional management accounting systems aimed to offer neutral, objective and calculable financial information. These systems were expected to bring to light the facts of costing, to enable pursuit of efficiency and help better regulate management labor relations. $\mathrm{ABC}$ is, therefore, the generic term to describe an alternative paradigm to traditional volume-based cost models. Its advocates claim that it is an accounting approach aimed primarily at understanding causality and giving decision-makers the potential to manage costs at the root, rather than a focus on product cost only.

$\mathrm{ABC}$ focus on those activities, which cause costs, and by identifying the activities required developing products. It has the potential to highlight the cost implications of adopting alternative methods and cost benefits which are available through the removal of non-conformance. It is also able to focus costs on customers and therefore assists in the isolation of non-value adding processes. Although it is unlikely that $\mathrm{ABC}$ will provide a relevant cost for all decisions and situations, but it will often provide a closer approximation. Another successful enterprise that adds to quality component strategy, which initiates the quality improvement, is the Total Quality Management (TQM). TQM emphasizes on education, training and cross-training employees to do multiple tasks. TQM may be seen as a system of behavior, which includes everyone in an organization and aims to involve and motivate staff at all levels, with an organizational philosophy that "Improvement is a way of life". TQM is rooted in personnel and production management, where each person emphasizes a certain characteristic of TQM. The characteristics include: -

Strategy - TQM forms an integral part of an enterprise's strategy and is therefore included in the business plan and the quality performance measures that are set.

- $\quad$ Training - A program for the training of all personnel in basic philosophy of quality management and improvement is essential. Each employee must have the opportunity for self-development, by means of continual training.

- $\quad$ Support - All qualifying initiatives must be supported by top management, whereby showing that they are the leaders of the cultural change. It must be clearly visible that this change begins actively at top management and is filtered down. 
- $\quad$ Involvement - All personnel must be regularly involved in quality projects, of which the success may be measured and disclosed. Personnel must identify ways which customers may receive better services.

- Customer Focus - The right to existence of all organizations is seated in the rendering of service to the customer. TQM is notably geared to delight the customer. It encompasses the monitoring of the change in the customer's needs over time.

- $\quad$ Process Management - Departments and individuals of an enterprise function by means of processes. To function effectively these processes must work in such a manner that personnel can experience the functioning of the individual departments as part of large a larger whole. These interdependencies, which are essential for the management of processes, must become visible by using the correct TQM performance measures.

- $\quad$ Prevention not correction - It is proved that customers are served better and preventing mistakes rather than correcting them once they occur controls costs more effectively. The aim should therefore be to get things right first time.

- $\quad$ Continuous Improvement - The belief that it is always possible to improve and so the aim should be to get it more right the next time.

Activity Based Management (ABM) is another example of Accounting Management tool, which are replacing the traditional accounting system. ABM uses detailed economic analysis of important business activities to improve strategic and operational decisions. ABM increases the accuracy of cost information by more precisely linking overhead and other indirect costs to products or customer segments. Traditional accounting systems distribute indirect costs using bases such as direct labor hours, machine hours or material dollars. ABM tracks overhead and other indirect costs by activity, which can then be traced to products or customers. ABM system can replace traditional accounting systems or operate as stand alone supplements. They require a strong commitment from both to management and line employees in order to succeed. To build a system that will support ABM, companies should;

- $\quad$ Determine key activities performed

- $\quad$ Determine cost drivers by activity

- $\quad$ Group overhead and other indirect costs by activity using clearly identified drivers

- $\quad$ Collect data on activity demands (by product and customer)

- $\quad$ Assign costs to products and customers (based on activity usage)

Therefore, the need is for the management accountant to remain closely in touch with the changes in the working environment and play a constructive role in the direction giving of these changes. As a result, it indicates that the management accounting function has the potential to play a significant path in the generation of quality strategy, irregular reporting for management control and in identifying, evaluating and prioritizing the various quality improvement projects which demonstrates improved profit performance.

The balanced scorecard is a strategic planning and management system that is used in business and industry. This helps for aligning the business activities to the vision and strategy of the organization. It was originated by Drs. Robert Kaplan (Harvard Business School) and David Norton as a performance measurement framework. The four perspectives of Balanced scorecard are The Learning \& Growth Perspective, The Business Process Perspective, The Customer Perspective and The Financial Perspective.

\section{KEEPING STEP WITH INFORMATION TECHNOLOGY}

The speed of technological change over the past years especially with the advent of Personal computers had a profound affect on the organizational life. Particularly significant over the past 5-10 years has been the extent of the dispersion of computers and computing capacity around the organization. The increased use of the computer has had major effects on the nature of work, especially clerical work and on information flows around the organizations. The various changes in competition, technology and organizational structure all have important implications for the nature of management accounting. One of the most important, apart from the speed and capacity of modern systems, has been the development of database technologies that provide the ability to store vast amounts of information in 
easily accessible ways. These technologies permit various users simultaneously to access the information stored on the database and to use it in different ways.

With modern databases, information can be analyzed in different ways. This makes it possible to design an information system that meets the need of various users, and in effect to have different purpose. Information which are needed from different accounting systems can easily be available although there is one database. These system are integrated through the information systems as a whole. Another significant effect of IT development is the way in which information is more widely dispersed around the organization. Managers and many other people at all levels with the organization have PC's available on their desks which can be used to access the information they need at any point of time. Compared to the traditional method, managers would ask accountants for the information especially the financial information they need. Some managers even maintain their own records, the formal information was maintained in the accounting system. If they need to access the information, they need to ask the accountants.

With the advancement of information system has become more integrated and access to them is dispersed around the organizations. Managers now have greater responsibility for information concerning their areas of activity. They can obtain the information directly from their PC at any time at their convenience. Thus managers seeking information from accountants and the accountants use the information stored in the information system to produce both financial and management accounting report. This implies a change in the role of management accountants, from one of information provider to the customer of broader integrated information system.

Enterprise resources planning (ERP) is a approach to consolidate all the company's departments and functions into a single computer system that services each department's specific needs. It is a convergence of people, hardware and software into an efficient production, service and delivery system that creates profit for the company With ERP, all elements in the supply and production chain can be easily accessed by all those who need the information. This results to efficiency in customer management and perceived company effectiveness in delivering on customer expectations.

\section{FUTURE TRENDS OF ENVIRONMENT \& FEATURES OF BUSINESS FIRMS}

Today business sectors have provided a fertile environment for the renewed interest and focus on the role of management accounting in business management. IFAC released a version of its International Management Accounting Practice Statement No 1, Management Accounting Concepts. The statement has 2 key elements: namely Describing management accounting by reference to leading edge practice internationally. And Describing a conceptual framework elaborating the description, identifying a set of assumptions for reasoning about appropriate directions for practice and criteria for evaluating good practice.

The success of new systems is being evaluated in term of decision-making and management evaluation of success. The key features of a business firm in attempting to strengthen their customer orientation and the success of the firm relies on the new management accounting systems. It is measured according to its usefulness in decisionmaking both from the staff units involved in customer related decisions and from organizational units with direct customer contact. In order to achieve this financial service companies are changing their management accounting systems in order to trace resource consumption more accurately to final products and customers by improving the conventional overhead-costing practice. The improvement of customer profitability analysis was an important aspiration for most of the accounting systems. 


\begin{tabular}{|c|c|}
\hline $\begin{array}{l}\text { Environment Of Business } \\
\text { Globalization } \\
\text { Customer Focus } \\
\text { Rapid Changes in Technology }\end{array}$ & $\begin{array}{l}\text { Responses by Business } \\
\text { Flattening Hierarchical Structures } \\
\text { World class manufacturing } \\
\text { Cell type of layout } \\
\text { Business to Business } \\
\text { Business to Customers } \\
\text { Reduce inventory costs } \\
\text { Value Chain }\end{array}$ \\
\hline & $\begin{array}{l}\text { Management Accounting Tools } \\
\text { Benchmarking } \\
\text { Activity Based Costing } \\
\text { Enterprise resources planning } \\
\text { Balanced Scorecard } \\
\text { Target costing } \\
\text { Supply chain management } \\
\text { Just in time inventory }\end{array}$ \\
\hline
\end{tabular}

\section{CONCLUSION}

Organization in the new millennium will need to adopt a more realistic approach to management. Managers require both traditional and non-traditional management accounting methods to make better decisions. Key determinants such as size, industry and strategic priorities have a differential impact on management practices. Size is significant for emerging practices, while industry is significant for traditional practices. Strategic priorities also affect the benefits from traditional and emergent practices. Managers need to be mindful of these organizational determinants and other such as the operating environment. There are implications for the need of management accounting to develop new approaches to address the new paradigm with the advancement of information technology. Management accounting will evolve as a useful tool for the managers to make decisions in the future.

\section{ACKNOWLEDGEMENT}

The authors would like to gratefully acknowledge the excellent research facilities and other support provided by King Fahd University of Petroleum \& Minerals, Dhahran, Saudi Arabia, to carry out this work.

\section{AUTHOR INFORMATION}

Dr. Mohammad Talha is currently working as Associate Professor in the Department of Accounting \& MIS, College of Industrial \& Management, King Fahd University of Petroleum \& Minerals (KFUPM), Dhahran, Saudi Arabia. He has published more than 100 research papers in national and international journals of repute. Dr. Talha has also authored three books on Management Accounting and Finance. His areas of specialization are: Financial Accounting \& Reporting, Managerial Accounting, International Accounting, Segmental disclosures, Merger \& Acquisition and Corporate Governance. He has supervised a number of doctorate and master students at the faculty. He can be contacted at talha@kfupm.edu.sa

Dr. John Bumani Raja is currently working as a faculty at Faculty of Business and Law, Multimedia University, Malaysia. Prior to this he was professor and Head, Department of Management Studies, National Institute of Technology, Trichirapalli, India. His area of research interest includes Management accounting corporate governance, Mutual funds and finance related topics. He has supervised three scholars at $\mathrm{PhD}$ level and 20 years of teaching experience at post graduate level. He has published a number of research papers in referred journals.

He can be contacted: john.raja@mmu.edu.my 
Prof. A. Seetharaman is basically a Chartered Accountant with $\mathrm{PhD}$ in Finance and Accounting. He secured first rank in his Master of Commerce Degree with specialization in Accounts and Audit. He also passed MBA in First Class with distinctions. He has published more than 100 articles in reputed international journals including those international journals listed in ISI Thomson and Scopus data bases. He was adjudged as Best Faculty among the academic staff of Management and business discipline of Multimedia University, Malaysia.

\section{REFERENCES}

1. Alfred Rappaport's (1986), Book - Creating Shareholder Value Free Press, a division of Simon \& Schuster, Inc., N.Y.

2. Anastas, M. (1997). The Changing World of Management Accounting and Financial Management. Management Accounting. October. 48-51.

3. Baden-Fuller, C. and Volberda, H.W. (1997). Strategic Renewal. How Large Complex Organizations Prepare for the Future. International Studies in Management and Organizations. 27. 2. Summer. 95-120.

4. Bettis, R.A. and Hitt, M.A. (1995). The New Competitive Landscape. Strategic Management Journal. 16. Summer. 7-19.

5. Brewer, Peter C.(2000),An Approach to Organizing a Management Accounting Curriculum. As published in Issues in Accounting Education, Vol 15, No 2, May 2000

6. Burns John E, Scapens, R. (2000) 'Conceptualising Management Accounting Change: an institutional framework', , London, Vol.10, 3-25, 1044-5005

7. Cooper, R. (1996). Look Out, Management Accountants. Management Accounting. May. 20-25.

8. Drucker, P.F. (1990), "The emerging theory of manufacturing”, Harvard Business Review, May/June1990, pp. 94-102.

9. $\quad$ Erkki.K Laintinen,Rolf Leppanen,(1999) Shareholders value as a management Tool, Towards integrated performance measurement system in the new Business Development, University of vaasa publications Reports and papers 43,1999 94p

10. Erkki K. Laitinen (2006) Explaining Management Accounting Change: evidence from Finland International Journal of Accounting, Auditing and Performance Evaluation Volume 3, Number 2 / 2006.

11. Gary Siegel's(2001), "Quality of Life in Management Accounting," Strategic Finance in sep 2001

12. Gerald Ross (1999) Counting More, Counting Less: Transformations in the Management Accounting Profession. : Strategic Finance, September 11999

13. Granlund, M. and Lukka, K. (1998). It's a Small World of Management Accounting Practices. Journal of Management Accounting Research. 10. 153-179.

14. Grundy, T. (1998). Managing the Business Value System. Management Accounting. December. 30-32.

15. G. Hofstede, "The Cultural Relativity of Organizational Practices and Theories," Journal of International Business Studies, 14, 1983

16. Jones, M.J., Munday, M., Brinn, T. (1998), "Speculations on barriers to the transference of Japanese management accounting", Accounting, Auditing \& Accountability Journal, Vol. 11 No.2, pp.204-15.

17. John Corrigan (1987) The renaissance of management accounting: New initiatives from different perspectives Australian CPA July 1, 1998

18. Jørn Flohr NielsenVan de Ven, A. H. \& Poole, M. S. (1995): "Explaining Development and Change in Organizations", Academy of Management Review, vol. 20, no. 3, pp. 510-540..

19. Johnson,H.T,Kaplan.R.S.(1987)Professional dominance: The relationship between financial accounting and managerial accounting, 1926-1986 Accounting Historians Journal, Dec 2002.

20. Johnson, H.T. (1995). Management Accounting in the 21st Century. Journal of Cost Management. Fall. 1519.

21. Juun-Min Lee, Richard CW Chen, Injazz Chen, Chen H Chung (2002), "A target costing based strategic decision support system", The Journal of Computer Information Systems, Vol. 43 No. 1, pp. 110-116

22. Lee Y. John (1994), "Use target costing to improve your bottom-line", The CPA Journal, Vol. 64 No. 1, pp. 68-73

23. Louis J Sarasohn Luehlfing, Michael S.,.(1996) Fixed assets don't squeak Management Accounting (USA)1996

24. Maccarone, P. (1998). Activity-based Management and the Product Development Process. European Journal of Innovation Management. 1. 3. 148-156. 
25. Marsden, A. (1998). Strategic Management. Which Way to Competitive Advantage? Management Accounting. January. 32-38.

26. Markus Granlund Teemu Malmi In Search of Management Accounting Theory European Accounting Review. Vol18,2009

27. Mouritsen, J. (1999). The Flexible Firm: Strategies for a Subcontractor's Management Control. Accounting, Organizations and Society. 24. 1. 31-55.

28. Ragnar Gotestam (1994)-world bank report-1994

29. Randall J. Cloud(2000) : Supply chain management New Role For Finance professionals Strategic Finance Volume: 82 Issue: 2 Page: 29

30. Shank, J.K. and Govindarajan, V. (1993). Strategic Cost Management. The New Tool for Competitive Advantage. The Free Press. New York.

31. Tom Kennedy, and Richard Bull ; ABC-Holy Grail or No Go Area?, Management Accounting, 78 (5), May 2000.

32. Yasuhiro Monden and John Lee.(1993) How a Japanese Automaker reduces costs?, Health Care Management Review 1993,page 71-77. 